ANL-7062

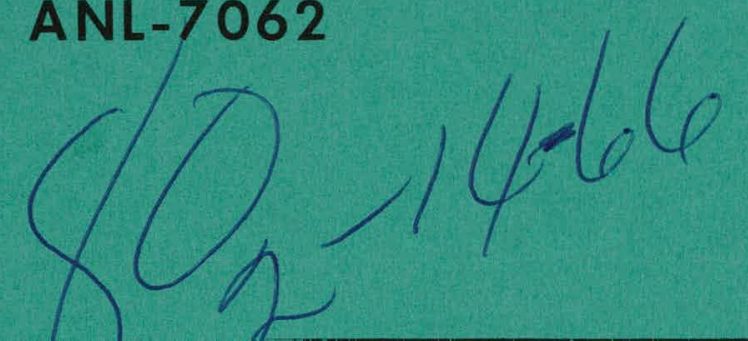

ANL-7062

Argonne Rational Laboratom

\title{
GLASSY MATERIALS FOR \\ NUCLEAR REACTOR APPLICATIONS
}

by

E. D. Lynch

RETHEASED FOR ANWOURECRUANS

IN NUCTEAR SCLJIECE ABSTIRACIS

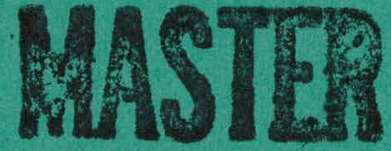




\section{DISCLAIMER}

This report was prepared as an account of work sponsored by an agency of the United States Government. Neither the United States Government nor any agency Thereof, nor any of their employees, makes any warranty, express or implied, or assumes any legal liability or responsibility for the accuracy, completeness, or usefulness of any information, apparatus, product, or process disclosed, or represents that its use would not infringe privately owned rights. Reference herein to any specific commercial product, process, or service by trade name, trademark, manufacturer, or otherwise does not necessarily constitute or imply its endorsement, recommendation, or favoring by the United States Government or any agency thereof. The views and opinions of authors expressed herein do not necessarily state or reflect those of the United States Government or any agency thereof. 


\section{DISCLAIMER}

Portions of this document may be illegible in electronic image products. Images are produced from the best available original document. 


\section{LEGAL NOTICE}

This report was prepared as an account of Government sponsored work. Neither the United States, nor the Commission, nor any person acting on behalf of the Commission:

A. Makes any warranty or representation, expressed or implied, with respect to the accuracy, completeness, or usefulness of the information contained in this report, or that the use of any information, apparatus, method, or process disclosed in this report may not infringe privately owned rights; or

B. Assumes any liabilities with respect to the use of, or for damages resulting from the use of any information, apparatus, method, or process disclosed in this report.

As used in the above, "person acting on behalf of the Commission" includes any employee or contractor of the Commission, or employee of such contractor, to the extent that such employee or contractor of the Commission, or employee of such contractor prepares, disseminates, or provides access to, any information pursuant to his employment or contract with the Commission, or his employment with such contractor.

Printed in USA. Price $\$ 2.00$. Available from the Clearinghouse for Federal

Scientific and Technical Information, National Bureau of Standards,

U. S. Department of Commerce, Springfield, Virginia 
RETEAASEDO FOR ANNOUNCEMENT

IN IUCTIAR SCTENICE ABSTRACTS
ANL-7062

Metals, Ceramics, and Materials (TID-4500, 47th Ed.)

AEC Research and Development Report

\title{
ARGONNE NATIONAL LABORATORY 9700 South Cass Avenue Argonne, Illinois 60439
}

\author{
GLASSY MATERIALS FOR \\ NUCLEAR REACTOR APPLICATIONS \\ by
} E. D. Lynch

Metallurgy Division

Final Report--Program 9.2.6

Program 9.2.7

Portions of the material in this report have appeared in the following ANL Metallurgy Division Progress Reports:

$\begin{array}{cc}\text { ANL } & \frac{\text { Page }}{96-101} \\ 6330 & 96-101-118 \\ 6516 & 97-100 \\ 6677 & 161-162 \\ 6868 & 47 \\ 7000 & \end{array}$

November 1965

Operated by The University of Chicago under

Contract W-31-109-eng-.38 with the U. S. Atomic Energy Commission

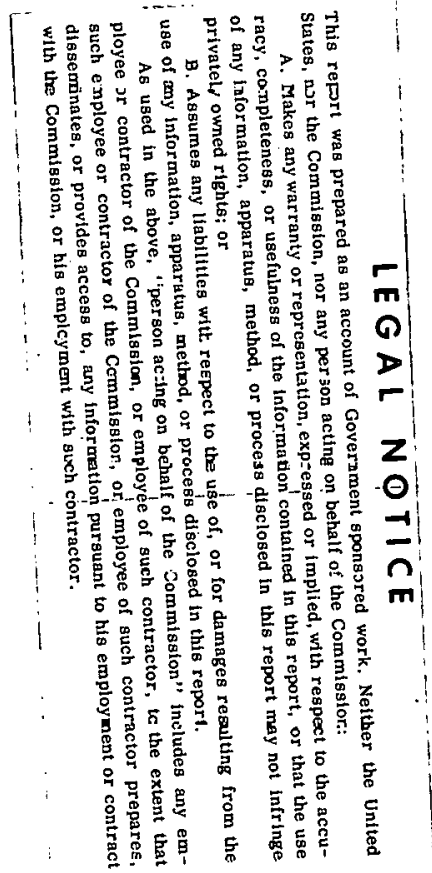


TAB LE OF CONTENTS

Page

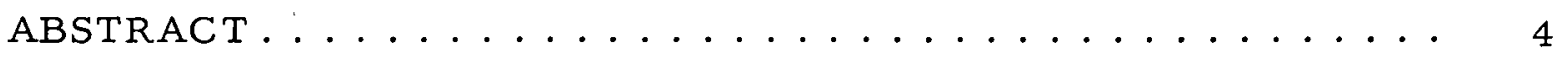

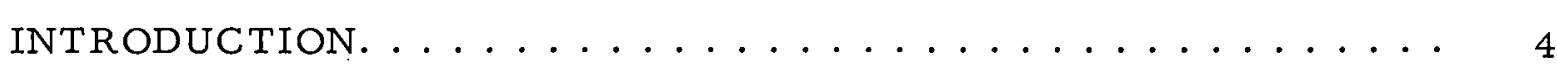

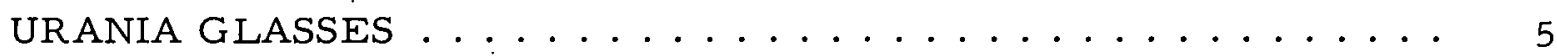

$\mathrm{PbO}-\mathrm{Na}_{2} \mathrm{O}-\mathrm{UO}_{2}-\mathrm{SiO}_{2} \mathrm{Glasses} \ldots \ldots \ldots \ldots_{7} \ldots \ldots \ldots \ldots$

$\mathrm{Na}_{2} \mathrm{O}-\mathrm{CaO}-\mathrm{UO}_{2}-\mathrm{SiO}_{2}$ Glasses ................... 7

$\mathrm{Na}{ }_{2} \mathrm{O}-\overline{\mathrm{UO}}_{3}-\mathrm{SiO}_{2} \mathrm{Glasses} \ldots \ldots \ldots \ldots . \ldots . \ldots . \ldots 10$

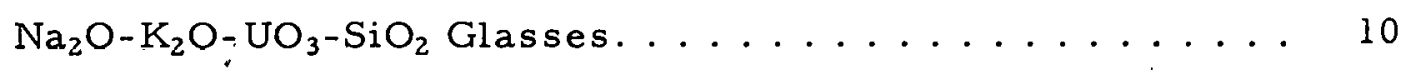

GLASSY MATERIALS FOR CONTROL-ROD USES . . . . . . . 14

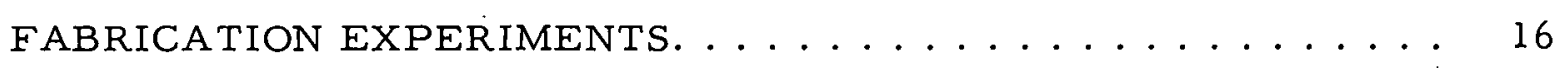

GLASSY COATING MATERLALS .................. 18

PRODUCTION OF DOPPLER-COEFFICIENT SAMPLES . . . . . . 20

GLASS-BONDED IRRADIATION SAMPLES . . . . . . . . . 21

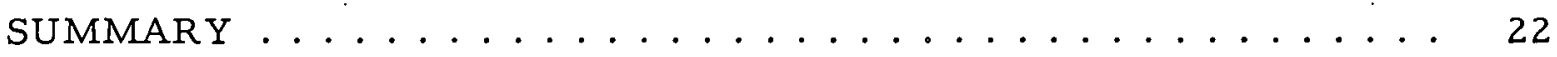

APPENDIX: Construction of Gradient Furnace ........... 24

ACKNOW LEDGMENT . . . . . . . . . . . . . . . . . . . 26 


\section{LIST OF FIGURES}

No.

Title

Page

1. Devitrification Characteristics of $\mathrm{Na}_{2} \mathrm{O}-\mathrm{CaO}-\mathrm{SiO}_{2}-\mathrm{UO}_{2}$

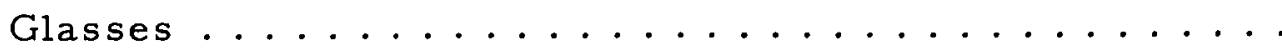

2. Variation in Density of $\mathrm{Na} 2 \mathrm{O}-\mathrm{CaO}-\mathrm{SiO}_{2}$ Glass with $\mathrm{UO}_{2}$

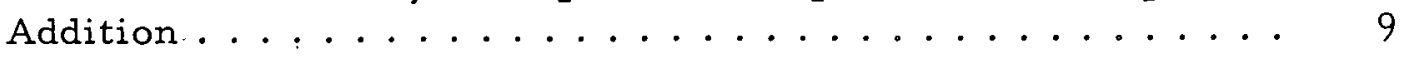

3. Devitrification Characteristics of $\mathrm{Na}_{2} \mathrm{O}-\mathrm{UO}_{3}-\mathrm{SiO}_{2}$ Glasses . $\quad 10$

4. Devitrification Characteristics of Glasses in the System $\mathrm{Na}_{2} \mathrm{O}-\mathrm{K}_{2} \mathrm{O}-\mathrm{UO}_{3}-\mathrm{SiO}_{2} \ldots \ldots \ldots \ldots$

5. Variation in Density of $\mathrm{Na}_{2} \mathrm{O}-\mathrm{K}_{2} \mathrm{O}-\mathrm{SiO}_{2}$ Glass with $\mathrm{UO}_{2}$

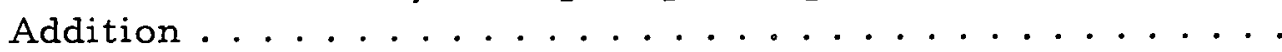

6. Thermal Expansion to Softening Point of Base and Fueled

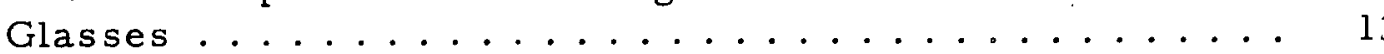

7. MgO-10 $\mathrm{w} / 0$ Glass Sintered at $1650^{\circ} \mathrm{C} \ldots \ldots \ldots$

\section{LIST OF TABLES}

No.

Title

Page

I. Devitrification Results for Some $\mathrm{PbO}-\mathrm{Na}_{2} \mathrm{O}-\mathrm{SiO}_{2}-\mathrm{UO}_{2}$

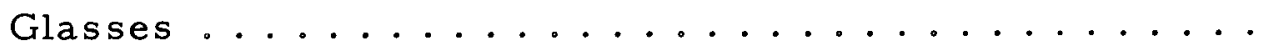

II. Devitrification Results for Some $\mathrm{Na}_{2} \mathrm{O}-\mathrm{CaO}-\mathrm{SiO}_{2}-\mathrm{UO}_{2}$

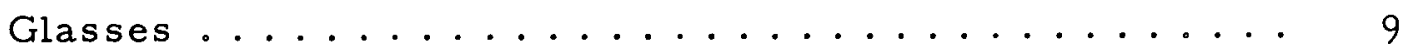

III. Devitrification Results for Some $\mathrm{Na}_{2} \mathrm{O}-\mathrm{UO}_{3}-\mathrm{SiO}_{2}$ Glasses. . 10

IV. Devitrification Resulls fus: Some $\mathrm{Na}_{2} \mathrm{O}-\mathrm{K}_{2} \mathrm{O}-\mathrm{UO}_{3}-\mathrm{SiO}_{2}$

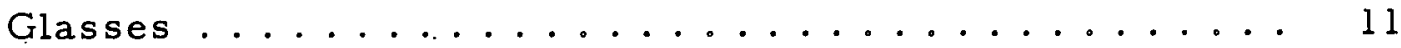

V. Sintering Data for MgO-Glass Mixtures ........... 16

VI. Cumulative Weight Loss (in grams) for Glazed Porcelain Tubing Subjected to Chemical Attack............

VII. Solubility of $\mathrm{Sr}^{90}$ for Glazes Subjected to Chemical Attack at Ronm Temperature... . . . . . . . . . . . 20

VIII. Compositions of Glasses Used in Irradiation Samples..... 


\author{
GLASSY MATERIALS FOR \\ NUCLEAR REACTOR APPLICATIONS
}

E. D. Lynch

\begin{abstract}
Studies were made to determine the feasibility of preparing fuel-bearing glasses and glasses bearing neutronabsorbing materials. Devitrification-resistant glasses were prepared that contained sufficient urania or rare-earth oxide to be used for fuel or control purposes, respectively.

Fabrication methods were devised to form crystallineglass mixtures to usable densities. Shapes were formed by pressing and sintering, warm pressing at $600^{\circ} \mathrm{C}$, vibratory compaction and sintering, and extrusion at $800^{\circ} \mathrm{C}$. A control-rod loading was fabricated by vibratory compaction of $\mathrm{B}_{4} \mathrm{C}$-glass into the cladding. Induction heating was used to bond the materials in the cladding tube. Glass-bonded uranium dioxide samples were prepared for Doppler-coefficient measurements.
\end{abstract}

Some work has been done on glassy coating materials for irradiation chambers and for neutron absorbers.

\title{
INTRODUCTION
}

Glassy materials have some characteristic propérties that could he of value in the solution of problems associated with the fabrication and use of crystalline fuel and control rods for reactors.

Glasses are inorganic liquids in which there is no long-range ordering of the structure. The viscosity of glasses is temperaturedependent, and, at low temperatures, most glasses behave as solids for all practical purposes. As a result of the structure and viscosity characteristics, glasses do not exhibit a melting point but rather a softening range. With increasing temperatures, glasses become less viscous until a condition of fluidity is reached. In the viscous range, glasses will yield to an applied stress, and the resulting strain can be removed by annealing. Since it will yield, a glassy material should not be prone to cracking and disintegration due to thermal stress or irradiation-induced stress during service. 
The thermal conductivity of glasses is low in general. At normal reactor operating temperatures, most glasses would flow to contact and wet the cladding. The good thermal contact with the cladding should result in improved heat-transfer characteristics. The effective thermal conductivity of the glassy materials could be improved with the incorporation of a higher-conductivity dispersed phase.

From the information available, it does not appear that glasses would be susceptible to a permanent irradiation damage that would impair their usefulness as fuels or controls. Further, glass lends itself to the incorporation of minor constituents, such as burnable poisons, and fuels in which glass is a major constituent should be readily reprocessed.

Primary areas of interest in the application of glassy materials to nuclear-reactor usage were: (1) the use of a glass containing fissile material as a single-phase fuel, (2) the use of a glass containing one or more high-thermal-cross-section materials as a single-phase control material, (3) the use of glass as a dispersion medium or bonding agent in admixture with crystalline high-cross-section control materials, and (4) the use of a fissile-glass as a dispersion medium and sintering agent in admixture with crystalline fissile materials.

\section{URANIA GLASSES}

Consideration was given to the development and study of fuelbearing glasses for operation in nuclear fuel systems, within the temperature limits of the readily available jacketing materials. -

For application as a reactor fuel, a glassy material should have the following general characteristics:

1. The glass should contain as high a. content of fissile material as possible without sacrifice of other desired properties.

2. The glass should be capable of yielding and viscous flow at the anticipated operating temperatures in order to minimize or anneal radiation damage and to prevent disintegration from thermal stress. In essence, this requires that the glass have a softening point below the operating temperature.

3. The glass should be capable of retaining integrity as a solution for long periods of time within the operating-temperature range. If there is a tendency to crystallize, subsequent crystal growth may lead to settling of crystals and uneven concentration of the fuel material. The tendency for such an event to occur will be dependent on the viscositytemperature characteristics of the glass within the operating-temperature range. 
4. The glassy material must be compatible with the jacketing metal since they will be in intimate contact at operating temperature.

The investigation of urania-glasses was directed toward the development of glasses having softening temperatures near $500^{\circ} \mathrm{C}$ and stability against devitrification in the temperature range of 300 to $1000^{\circ} \mathrm{C}$.

Since the field of glass compositions is virtually unlimited, this preliminary study was confined to simple, proven, glass systems that appeared to have the greatest merit. No effort was made to study the influence of minor constituents or to do a comprehensive study of glass properties. This study was limited to the determination of the solubility of uranium oxide in glasses, the change in density resulting from urania additions, and the devitrification behavior of urania-bearing glasses. Measurements were made of the thermal-expansion properties of selected materials.

To avoid devitrification at relatively low temperatures, it is desirable that the glass have a low liquidus temperature. The viscositytemperature relationship of the glass will influence the rate of crystallization, but when the liquidus temperature and the operating temperature approach the same.value, crystallization is more apt to occur.

Since the oxides of uranium are not glass formers, they were considered as constituents along with glass formers such as $\mathrm{SiO}_{2}$ and $\mathrm{P}_{2} \mathrm{O}_{5}$. For the present investigation, $\mathrm{B}_{2} \mathrm{O}_{3}$ was eliminated because of its high neutron-absorption cross section.

The materials used in the preparation of glasses weretechnicalgrade chemicals, except for the silica, which was a commercial grade. Urania was added as ceramic-grade oxide and as uranates formed from this oxide.

Glasses were prepared by melting the base glass composition, quenching, and crushing to about $60-\mathrm{mesh}$ size. Urania additions were - made to the crushed-glass cullet, and the resulting composition was remelted. Melting was carried out in platinum crucibles in the temperature range of 1400 to $1500^{\circ} \mathrm{C}$. Following this melting, the crucibles of molten glass were air-quenched.

The solubility limit of urania in the glasses during melting was determined by microscopic examination of glass chips for a crystalline phase. Since compositional variations were wide, the limits of solubility were.not precisely located.

The devitrification resistance was determined by maintaining a glass sample in a temperature gradient until crystal formation was 
observed. Samples for test were placed in a furnace in $0.64 \mathrm{x} 0.64 \mathrm{x}$ $17.8-\mathrm{cm}$ platinum boats. The furnace winding was such that a $650^{\circ} \mathrm{C}$ temperature gradient (at approximately 300 to $950^{\circ} \mathrm{C}$ ) could be maintained across the length of the boat. An additional feature of the gradient furnace was a full-length window so that the glass could be observed visually or microscopically during the test. Temperature measurements were made with a thermocouple along the side of the boat. This furnace is described in detail in the appendix.

Density measurements were made by the suspended-weight method on chunks of unannealed glass broken from crucible melts. Bubble-free pieces were selected for measurement, and water was used as the suspension medium.

Review of the phase diagrams showed low-liquidus-temperature compositions of interest in the systems $\mathrm{Na}_{2} \mathrm{O}-\mathrm{CaO}-\mathrm{SiO}_{2}, \mathrm{PbO}-\mathrm{Na} \mathrm{N}_{2} \mathrm{O}-\mathrm{SiO}_{2}$, $\mathrm{Na}_{2} \mathrm{O}-\mathrm{SiO}_{2}$, and $\mathrm{Na}_{2} \mathrm{O}-\mathrm{K}_{2} \mathrm{O}-\mathrm{SiO}_{2}$, and representative glasses were selected from these systems for a screening study.

$\underline{\mathrm{PbO}-\mathrm{Na}_{2} \mathrm{O}-\mathrm{UO}_{2}-\mathrm{SiO}_{2} \text { Glasses }}$

Two glasses having low liquidus temperatures were selected for study from this system. The compositions of these glasses were $62.1 \mathrm{w} / \mathrm{oPbO}-$ $10.0 \mathrm{w} / \mathrm{oNa}_{2} \mathrm{O}-27.9 \mathrm{w} / \mathrm{oSiO}_{2}$, and $64.0 \mathrm{w} / \mathrm{oPbO}-9.4 \mathrm{w} / \mathrm{oNa}{ }_{2} \mathrm{O}-26.6 \mathrm{w} / \mathrm{oSiO} \mathrm{S}_{2}$. Both glasses were subjected to a $650^{\circ} \mathrm{C}$ thermal gradient at temperatures of 300 to $950^{\circ} \mathrm{C}$ for 7 days without crystallization occurring. Of the two compositions, the latter was chosen to determine the effects of $\mathrm{UO}_{2}$ additions on this type of glass. Initial melting tests showed a frothing problem during melting due to the oxidation of $\mathrm{UO}_{2}$ prior to solution. To overcome this problem, urania additions were normally made as $\mathrm{U}_{3} \mathrm{O}_{8}$.

The results of the addition of urania to this base-glass composition are shown in Table I. Urania additions decreased the resistance to crystallization of the base glass. The most devitrification-resistant of the urania-bearing glass was the composition in which urania was added as $\mathrm{PbUO}_{4}$. None of the urania-bearing glasses in this system exhibited sufficient devitrification resistance to merit further investigation.

$\underline{\mathrm{Na}_{2} \mathrm{O}-\mathrm{CaO}-\mathrm{UO}_{2}-\mathrm{SiO}_{2} \text { Glasses }}$

The base composition chosen for exploration in this system was that of a commercial glass, neglecting minor additions: $16.5 \mathrm{w} / \mathrm{oNa}_{2} \mathrm{O}-$ $10.9 \mathrm{w} / \mathrm{oCaO}-72.6 \mathrm{w} / \mathrm{oSiO}_{2}$. Compositions were prepared by melting $60-$ mesh cullet of the base composition with $\mathrm{U}_{3} \mathrm{O}_{8}$.

Melts containing up to approximately $30 \mathrm{w} / \mathrm{o} \mathrm{UO}_{2}$ were uniformlycolored, greenish-yellow glasses. Above this amount, the glasses were 
considerably darker, and undissolved particles were apparent in glas ses containing $60 \mathrm{w} / \circ \mathrm{UO}_{2}$ and greater. The compositions containing 80 and $90 \mathrm{w} / 0 \mathrm{UO}_{2}$ were essentially $\mathrm{UO}_{2}$ sintered with a glassy bond.

TABLE I. Devitrification Results for Some $\mathrm{PbO}-\mathrm{Na}_{2} \mathrm{O}-\mathrm{SiO}_{2}-\mathrm{UO}_{2}$ Glasses

\begin{tabular}{|c|c|c|c|c|}
\hline \multicolumn{4}{|c|}{ Composition, w/o } & \multirow{2}{*}{ Devitrification Results } \\
\hline $\mathrm{PbO}$ & $\mathrm{Na}_{2} \mathrm{O}$ & $\mathrm{SiO}_{2}$ & $\begin{array}{c}\mathrm{UO}_{2} \\
\text { Addition }\end{array}$ & \\
\hline 62.1 & 10.0 & 27.9 & & $\begin{array}{l}\text { No crystallization in } 7 \text { days, } \\
300-950^{\circ} \mathrm{C} \text { gradient. }\end{array}$ \\
\hline 64.0 & 9.4 & 26.6 & & $\begin{array}{l}\text { No crystallization in } 7 \text { days, } \\
300-950^{\circ} \mathrm{C} \text { gradient. }\end{array}$ \\
\hline 64.0 & 9.4 & 26.6 & 9.8 & $\begin{array}{l}\text { Small crystals formed in } 5 \mathrm{hr} \\
\text { between } 480 \text { and } 715^{\circ} \mathrm{C} \text {; no extensive } \\
\text { growth in } 7 \text { days. }\end{array}$ \\
\hline 64.0 & 9.4 & 26.6 & 23.1 & $\begin{array}{l}\text { Crystallized completely during } \\
\text { melting of sample in gradient } \\
\text { boat. }\end{array}$ \\
\hline 64.0 & 9.4 & 26.6 & 32.9 & $\begin{array}{l}\text { Crystallized completely during } \\
\text { melting of sample.in gradient } \\
\text { boat. }\end{array}$ \\
\hline 64.0 & 9.4 & 26.6 & $9.7 *$ & $\begin{array}{l}\text { Crystals formed at } 560-680^{\circ} \mathrm{C} \text { in } \\
5 \mathrm{hr} \text {; no change in } 7 \text { days. }\end{array}$ \\
\hline 64.0 & 9.4 & 26.6 & $8.9 * *$ & $\begin{array}{l}\text { Few crystals developed at } 500^{\circ} \mathrm{C} \text { in } \\
1 \text { day; no change in } 5 \text { days. }\end{array}$ \\
\hline
\end{tabular}

$* \mathrm{UO}_{2}$ added as $\mathrm{Nad}_{2} \mathrm{UO}_{4}$.

$* * \mathrm{UO}_{2}$ added as $\mathrm{PbUO}_{4}$.

The results of heating these glasses in the gradient furnace are shown in Table II and Fig. 1. Glasses containing up to approximately $40 \mathrm{w} / 0 \mathrm{UO}_{2}$ were resistant to devitrification, but the temperature range of stability was below that desired in this preliminary study. The addition of up to approximately $40 \mathrm{w} / \mathrm{o} \mathrm{UO}_{2}$ did not greatly affect the liquidus temperature of the base-glass composition.

These glasses showed a wide range of solubility of urania and a more limited.range of devitrification-resistant glasses. A further evaluation was made of the change in density of the base glass resulting from. urania additions. The density varied from $2.51 \mathrm{~g} / \mathrm{cc}$ for the base glass to $4.61 \mathrm{~g} / \mathrm{cc}$ for the approximately $70 \mathrm{w} / \mathrm{O} \mathrm{UO}_{2}$ addition. Variations in density with $\mathrm{UO}_{2}$ additions are shown in Fig. 2 . 
TABLE II. Devitrification Results for Some $\mathrm{Na}_{2} \mathrm{O}-\mathrm{CaO}-\mathrm{SiO}_{2}-\mathrm{UO}_{2}$. Glasses

\begin{tabular}{|c|c|c|c|c|}
\hline \multicolumn{4}{|c|}{ Composition, w/o } & \multirow{2}{*}{$\begin{array}{c}\text { Devitrification Results } \\
\text { ( } 7 \text { days in gradient } 300-950^{\circ} \mathrm{C} \text { ) }\end{array}$} \\
\hline $\mathrm{Na}_{2} \mathrm{O}$ & $\mathrm{CaO}$ & $\mathrm{SiO}_{2}$ & $\begin{array}{c}\mathrm{UO}_{2} \\
\text { Addition }\end{array}$ & \\
\hline 16.5 & 10.9 & 72.6 & & $\begin{array}{l}\text { Pronounced crystallization above } 720^{\circ} \mathrm{C} \text {, } \\
\text { none below. }\end{array}$ \\
\hline 16.5 & 10.9 & 72.6 & 9.8 & $\begin{array}{l}\text { Pronounced crystallization above } 740^{\circ} \mathrm{C} \text {, } \\
\text { none below. }\end{array}$ \\
\hline 16.5 & 10.9 & 72.6 & 19.4 & $\begin{array}{l}\text { Pronounced crystallization above } 725^{\circ} \mathrm{C} \text {, } \\
\text { none below. }\end{array}$ \\
\hline 16.5 & 10.9 & 72.6 & 29.3 & $\begin{array}{l}\text { Pronounced crystallization above } 700^{\circ} \mathrm{C} \text {, } \\
\text { none below. }\end{array}$ \\
\hline .16 .5 & 10.9 & 72.6 & 38.9 & $\begin{array}{l}\text { Some crystallization at } 300-700^{\circ} \mathrm{C} \text {, more } \\
\text { pronounced above } 700^{\circ} \mathrm{C} .\end{array}$ \\
\hline 16.5 & 10.9 & 72.6 & 48.9 & $\begin{array}{l}\text { Some crystallization at } 300-650^{\circ} \mathrm{C} \text {, more } \\
\text { pronounced above } 650^{\circ} \mathrm{C} .\end{array}$ \\
\hline 16.5 & 10.9 & 72.6 & 59.5 & $\begin{array}{l}\text { Some crystallization at } 300-650^{\circ} \mathrm{C} \text {, more } \\
\text { pronounced above } 650^{\circ} \mathrm{C} .\end{array}$ \\
\hline 16.5 & 10.9 & 72.6 & 68.5 & Heavy crystallization over entire range. \\
\hline 16.5 & 10.9 & 72.6 & 79.1 & Not determined. \\
\hline 16.5 & 10.9 & 72.6 & 89.6 & Not determined. \\
\hline
\end{tabular}

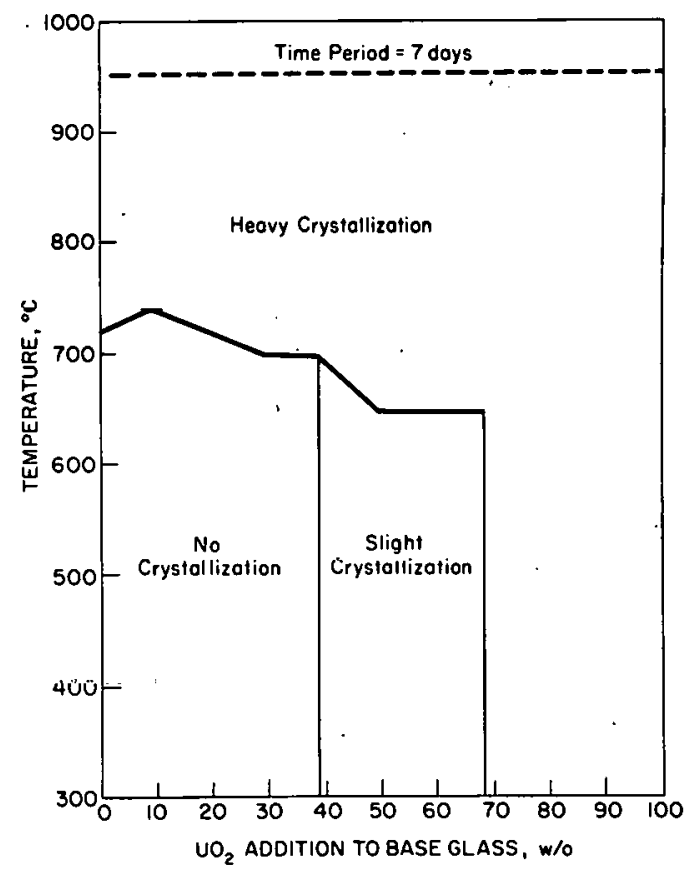

$106-5868$ Rev

- Fig. 1. Devitrification Characteristics of $\mathrm{Na}_{2} \mathrm{O}-\mathrm{CaO}-\mathrm{SiO}_{2}-\mathrm{UO}_{2}$ Glasses

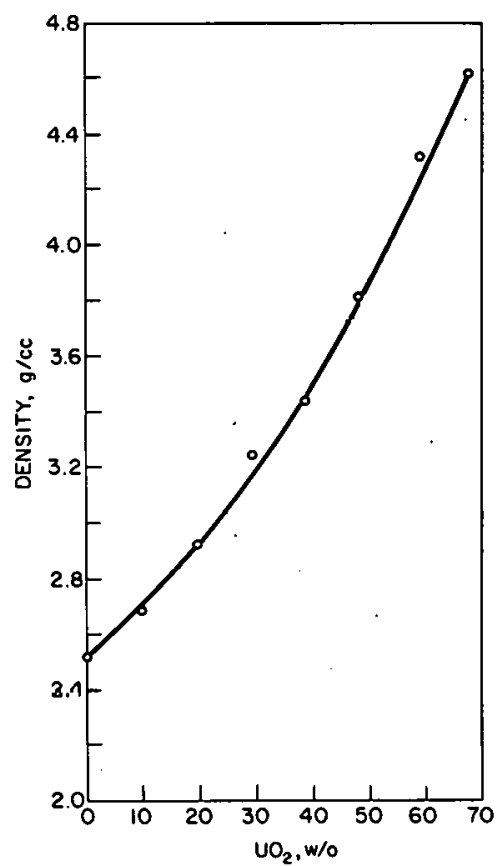

106-5870 Rev.

Fig. 2. Variation in Density of $\mathrm{Na}_{2} \mathrm{O}-\mathrm{CaO}-\mathrm{SiO}_{2}$ Glass with $\mathrm{UO}_{2}$ Addition 
$\mathrm{Na}_{2} \mathrm{O}-\mathrm{UO}_{3}-\mathrm{SiO}_{2}$ Glasses

The alkali disilicates are considered devitrification-resistant glasses. A series of glasses was prepared based on $\mathrm{Na}_{2} \mathrm{Si}_{2} \mathrm{O}_{5}$ in which the uranium oxide was added as $\mathrm{Na}_{2} \mathrm{UO}_{4}$ for convenience in melting. These glasses were prepared in a single melting process.

Urania additions equivalent to $43.7 \mathrm{w} / \mathrm{O} \mathrm{UO}_{3}$ were melted, with no indication of urania insolubility or precipitation.

When examined in the thermal-gradient furnace, the glasses were found to be prone to devitrification at approximately the middle of the temperature range of interest. Results of the gradient tests are shown in Table III and Fig. 3. Crystallization began in all glasses after approximately 2 days in the gradient 300 to $950^{\circ} \mathrm{C}$ but did not progress appreciably in 7 days. Compositions containing up to approximately $26 \mathrm{w} / 0 \mathrm{UO}_{3}$ appear to be of interest when below or above the range of 600 to $800^{\circ} \mathrm{C}$.

TABLE III. Devitrification Results for Some $\mathrm{Na}_{2} \mathrm{O}-\mathrm{UO}_{3}-\mathrm{SiO}_{2}$ Glasses

\begin{tabular}{|c|c|c|c|}
\hline \multicolumn{3}{|c|}{ Composition, w/o } & \multirow{2}{*}{$\begin{array}{c}\text { Devitrification Results } \\
\text { ( } 7 \text { days in gradicnt } 300-950^{\circ} \mathrm{C} \text { ) }\end{array}$} \\
\hline $\mathrm{Na}_{2} \mathrm{O}$ & $\mathrm{UO}_{3}$ & $\mathrm{SiO}_{2}$ & \\
\hline 31.4 & - & 68.6 & $\begin{array}{l}\text { Crystals formed after } 2 \text { days } \\
\text { in range of } 550-800^{\circ} \mathrm{C} \text {. }\end{array}$ \\
\hline 28.0 & 9.2 & 62.8 & $\begin{array}{l}\text { Crystals formed after } 2 \text { days } \\
\text { in range of } 600-615^{\circ} \mathrm{C} \text {. }\end{array}$ \\
\hline 30.0 & 17.5 & 52.5 & $\begin{array}{l}\text { Crystals formed after } 2 \text { days } \\
\text { in range of } 616-790^{\circ} \mathrm{C} \text {. }\end{array}$ \\
\hline 28.0 & 25.9 & 46.1 & $\begin{array}{l}\text { Crystals formed after } 2 \text { days } \\
\text { in range of } 725-800^{\circ} \mathrm{C} .\end{array}$ \\
\hline 26.2 & 34.0 & 39.8 & $\begin{array}{l}\text { Crystal's formed after } 2 \text { days } \\
\text { in range of } 725-950^{\circ} \mathrm{C} \text {. }\end{array}$ \\
\hline 23.8 & 43.7 & 32.5 & $\begin{array}{l}\text { Crystals formed after } 2 \text { days } \\
\text { in range of } 725-950^{\circ} \mathrm{C}\end{array}$ \\
\hline
\end{tabular}

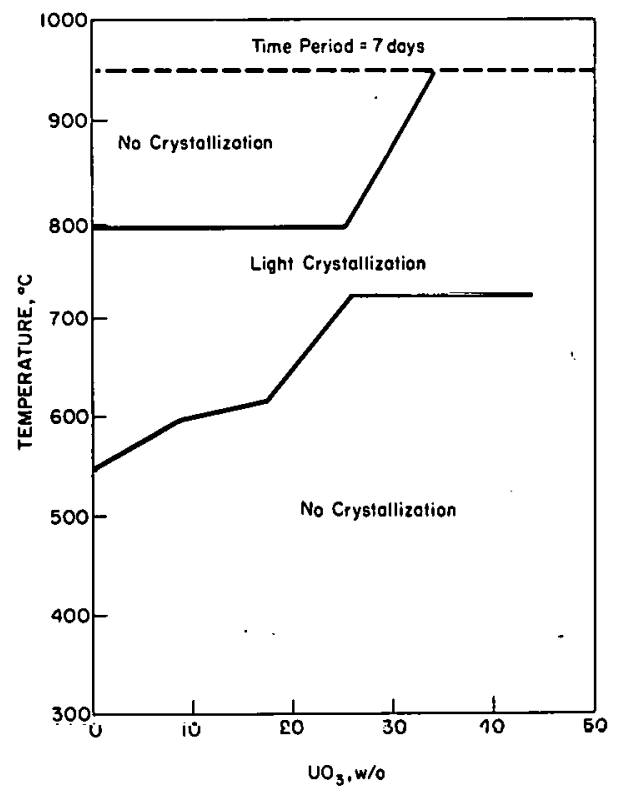

106-5867 Rev.

Fig. 3. Devitrification Characteristics of $\mathrm{Na}_{2} \mathrm{O}-\mathrm{UO}_{3}-\mathrm{SiO}_{2}$ Glasses

$\underline{\mathrm{Na}_{2} \mathrm{O}-\mathrm{K}_{2} \mathrm{O}-\mathrm{UO}_{3}-\mathrm{SiO}_{2} \text { Glasses }}$

To investigate further the possibilities of the simple silicate glasses, a composition from the system $\mathrm{Na}_{2} \mathrm{O}-\mathrm{K}_{2} \mathrm{O}-\mathrm{SiO}_{2}$ was selected that would be expected to be devitrification-resistant on the bases of having a low liquidus temperature and an alkali disilicate as the primary phase. The composition used was $10 \mathrm{w} / 0 \mathrm{Na}_{2} \mathrm{O}-20 \mathrm{w} / 0 \mathrm{~K}_{2} \mathrm{O}-70 \mathrm{w} / 0 \mathrm{SiO}_{2}$. Glass of this composition was held in the gradient furnace $\left(300-950^{\circ} \mathrm{C}\right)$ for 14 days with no indication of crystal formation. 
Glass compositions prepared by melting the base glass and $\mathrm{U}_{3} \mathrm{O}_{8}$ were greenish-yellow in color but, on being left in the gradient furnace, changed to yellowish-orange, indicative of a change to the $\mathrm{U}^{6+}$ state. It seemed likely that addition of urania as the uranate would prevent such a change that could result in alteration of the base-glass composition during heating. The glasses were then prepared with uranates and combinations of uranates as the source of the urania. These glasses were easier to melt and had the yellowish-orange color following melting.

The devitrification behaviors of both series were similar, and the results shown in Table'IV and Fig. 4 are for glasses prepared by uranate additions. Compositions in this series containing urania additions equivalent to approximately $30 \mathrm{w} / \mathrm{o} \mathrm{UO}_{2}$ have shown remarkable resistance to crystallization. These compositions showed no crystallization after 14 days in the gradient furnace, and one composition has been held for 100 days without devitrification.

TABLE IV. Devitrification Results for Some $\mathrm{Na}_{2} \mathrm{O}-\mathrm{K}_{2} \mathrm{O}-\mathrm{UO}_{3}-\mathrm{SiO}_{2}$ Glasses

\begin{tabular}{|c|c|c|c|c|}
\hline \multicolumn{4}{|c|}{ Composition, w/o } & \multirow{2}{*}{$\begin{array}{c}\text { Devitrification Results } \\
\text { (14 days in gradient } 300-950^{\circ} \mathrm{C} \text { ) }\end{array}$} \\
\hline $\mathrm{Na}_{2} \mathrm{O}$ & $\mathrm{K}_{2} \mathrm{O}$ & $\mathrm{SiO}_{2}$ & $\mathrm{UO}_{3}$ & \\
\hline 10.6 & 19.8 & 69.6 & - & No crystallization. \\
\hline 11.3 & 17.8 & 62.9 & $7.9^{\mathrm{a}}$ & No crystallization. \\
\hline 12.1 & 15.9 & 55.8 & $16.4^{\mathrm{a}}$ & No crystallization. \\
\hline 12.7 & 14.0 & 48.8 & $24.5^{\mathrm{a}}$ & Very few crystals at $560-800^{\circ} \mathrm{C}$. \\
\hline 13.5 & 11.9 & 41.8 & $32.8^{\mathrm{a}}$ & Pronounced crystallization at $740-950^{\circ} \mathrm{C}$. \\
\hline 14.3 & 9.7 & 34.2 & $41.8^{a}$ & $\begin{array}{l}\text { Devitrification over entire range in } \\
24 \mathrm{hr} \text {. }\end{array}$ \\
\hline 9.5 & 20.4 & 62.3 & $7.9^{b}$ & No crystallization. \\
\hline 8.4 & 20.1 & 54.7 & $16.1^{\mathrm{b}}$ & No crystallization. \\
\hline 7.4 & 21.3 & 48.5 & $22.8^{b}$ & No crystallization. \\
\hline 6.5 & 21.8 & 42.4 & $29.4^{\mathrm{b}}$ & Crystals formed at $760-850^{\circ} \mathrm{C}$. \\
\hline 5.3 & 22.3 & 34.8 & $37.6^{\mathrm{b}}$ & $\begin{array}{l}\text { Devitrification over entire range in } \\
24 \mathrm{hr} \text {. }\end{array}$ \\
\hline 10.2 & 18.4 & 55.2 & $16.2^{\mathrm{C}}$ & No crystallization.* \\
\hline 9.2 & 18.9 & 48.4 & $23.6^{\mathrm{c}}$ & No crystallization. \\
\hline 11.0 & 16.3 & 48.4 & $24.3^{c}$ & No crystallization. \\
\hline 8.1 & 19.4 & 41.6 & $30.9^{\mathrm{C}}$ & No crystallization. \\
\hline 9.9 & 16.9 & 41.5 & $31.7^{\mathrm{c}}$ & A few small crystals at $760^{\circ} \mathrm{C}$. \\
\hline 11.7 & 14.4 & 42.0 & $31.9^{c}$ & A few small crystals at $550-800^{\circ} \mathrm{C}$. \\
\hline
\end{tabular}

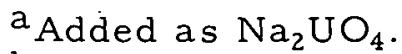

${ }^{b}$ Added as $\mathrm{K}_{2} \mathrm{UOO}_{4}$.

c Added as mixtures of $\mathrm{Na}_{2} \mathrm{UO}_{4}$ and $\mathrm{K}_{2} \mathrm{UO}_{4}$.

*No crystallization after 100 days. 


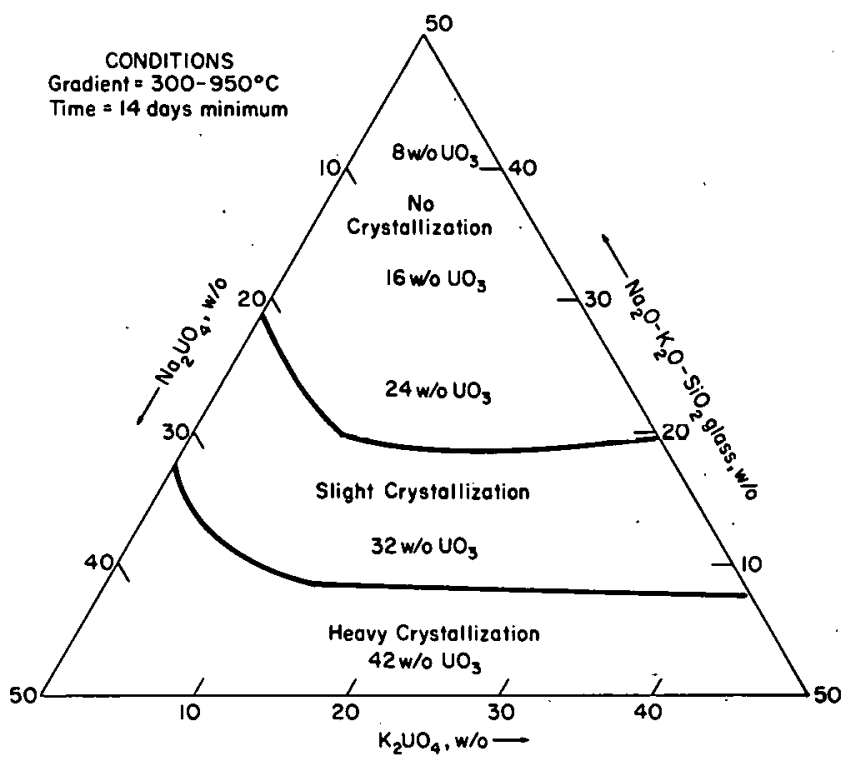

106-5866 Rev.

Fig. 4. Devitrification Characteristics of Glasses in the System $\mathrm{Na}_{2} \mathrm{O}-\mathrm{K}_{2} \mathrm{O}-\mathrm{UO}_{3}-\mathrm{SiO}_{2}$
To obtain the limit of urania solubility and the density changes in this system, a series of glasses was melted in which up to $90 \mathrm{w} / \mathrm{o} \mathrm{UO}_{2}$ was added to the glass. Urania additions were made as $\mathrm{UO}_{2}$ to keep the com:ponents of the base glass in a constant ratio. There were no crystals apparent, by visual observation after melting, in compositions containing up to $60 \mathrm{w} / \mathrm{OUO}_{2}$ in the glass. Compositions containing 80 and $90 \mathrm{w} / 0 \mathrm{UO}_{2}$ did not contain glas's as the major phase after melting. Density variations (Fig. 5) were from $2.44 \mathrm{~g} / \mathrm{cc}$ for the base glass, to $4.18 \mathrm{~g} / \mathrm{cc}$ for the glass containing $60 \mathrm{w} / \mathrm{o} \mathrm{UO}_{2}$ in solution, and $4.78 \mathrm{~g} / \mathrm{cc}$ for the $70-\mathrm{w} / \mathrm{o} \mathrm{UO}_{2}$ composition, in which the $\mathrm{UO}_{2}$ was not completely in solution after melting.

Thermal expansion was determined for the soda-potassia-silica base glass and for this glass containing $35 \mathrm{w} / \mathrm{o} \mathrm{UO}_{2}$ addition. The thermal expansion was determined in air, to the softening point, by an interferometric method. The results are shown in Fig. 6.

Fig. 5

Variation in Density of $\mathrm{Na}_{2} \mathrm{O}-\mathrm{K}_{2} \mathrm{O}-\mathrm{SiO}_{2}$ Glass with $\mathrm{UO}_{2}$ Addition

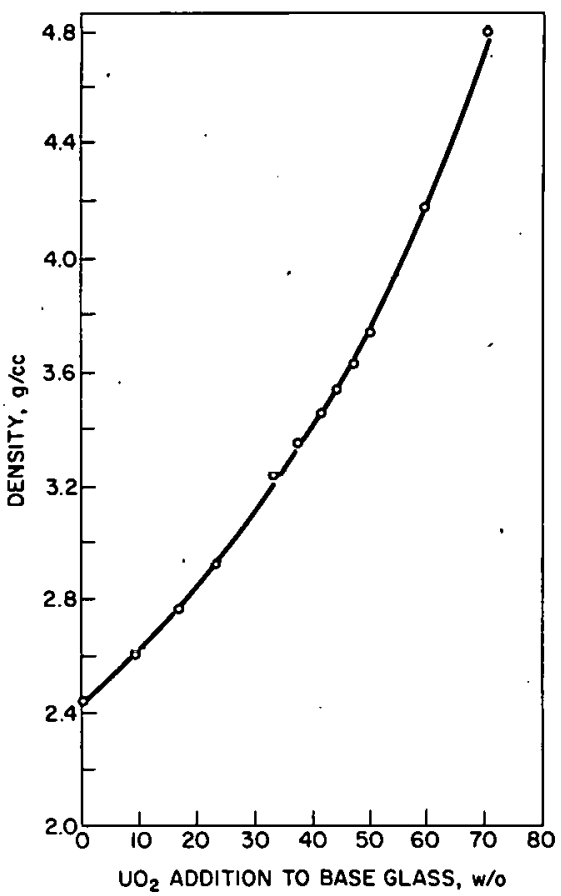




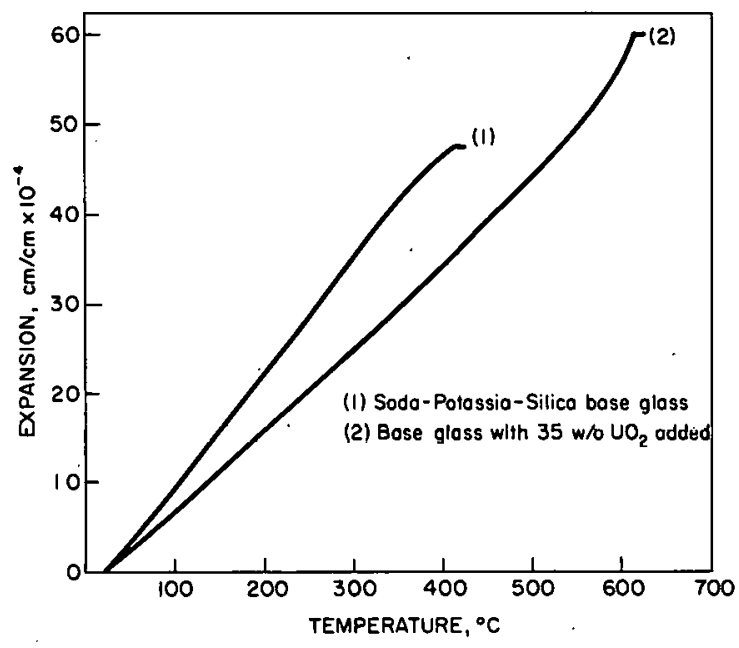

Fig. 6

Thermal Expansion to Softening Point of Base and Fueled Glasses

The addition of $\mathrm{UO}_{2}$ to the base glass resulted in a lower coefficient of expansion. For the base glass, the linear coefficient of expansion, in the range of 25 to $300^{\circ} \mathrm{C}$, was $12.9 \times 10^{-6} \mathrm{~cm} / \mathrm{cm} /{ }^{\circ} \mathrm{C}$; for the glass containing $35 \mathrm{w} / \mathrm{o} \mathrm{\textrm {UO } _ { 2 }}$, the coefficient was $9.4^{-} \times 10^{-6} \mathrm{~cm} / \mathrm{cm} /{ }^{\circ} \mathrm{C}$ in the range of 25 to $500^{\circ} \mathrm{C}$. The addition of the $35 \mathrm{w} / \circ \mathrm{UO}_{2}$ also resulted in an increase in the softening point from approximately 425 to $625^{\circ} \mathrm{C}$. 


\section{GLASSY MATERIALS FOR CONTROL-ROD USES}

Several rare-earth metals have high neutron-absorption cross sections and could find application as control-rod materials. Because of the very high cross section of these materials, only small quantities are required to be uniformly distributed in the control-rod geometry.

An efficient way of obtaining a uniform concentration of these materials would be by dissolution in a suitable medium. Glass as a solution medium for rare-earth oxides should be of value since the concentration distribution would be uniform and the material acts as a solid at ordinary temperatures.

The glassy material for this purpose does not have any special requirements except that there should be no crystals separate during cooling of the melt since such an occurrence would affect the degree of homogeneity. The usual control-rod temperature is low enough that devitrification in use would probably not occur.

The alkali-silicate glass $\left(10 \mathrm{w} / \mathrm{ONa}_{2} \mathrm{O}-20 \mathrm{w} / \mathrm{oK}_{2} \mathrm{O}-70 \mathrm{w} / \mathrm{oSiO}_{2}\right)$ that had been proven resistant to devitrification was used as the base glass for exploration of the solubility of rare-earth oxides.

Europium oxide in the amount of 5,10 , and $15 \mathrm{w} / 0$ was added to the alkali-silicate base glass. These compositions were easily melted at 1200 to $1400^{\circ} \mathrm{C}$ and formed a uniformly-colored, light-brown glass that was free from crystalline phases after cooling from the melt. These glasses were tested for 7 days in the gradient furnace $\left(300\right.$ to $\left.1000^{\circ} \mathrm{C}\right)$, and there was no tendency for crystallization in this temperature range.

The solubility range of rare-earth oxides in two base glasses was determined by preparing melts containing additions, in $10-\mathrm{w} / 0$ increments, of $\mathrm{Gd}_{2} \mathrm{O}_{3}, \mathrm{Dy}_{2} \mathrm{O}_{3}, \mathrm{Gd}_{2} \mathrm{O}_{3}-\mathrm{Sm}_{2} \mathrm{O}_{3}$, and $\mathrm{Eu}_{2} \mathrm{O}_{3}$. Additions were made to the sodacalcia-silica and the soda-potassia-silica glasses previously described.

Melting was carried out in platinum crucibles at $1500^{\circ} \mathrm{C}$. The glasses were water-quenched after melting and examined microscopically for evidence of crystallization or incomplete solution during melting.

The maximum solubility of rare-earth oxides was in the sodapotassia-silica glass. In this glass, all the oxides used were soluble to a level of $30 \mathrm{w} / 0$. At $40 \mathrm{w} / \mathrm{o}$ rare-earth oxide addition, some crystallization occurred; above $50 \mathrm{w} / \mathrm{o}$ addition, the result was primarily crystalline phases in a glassy matrix. In the soda-calcia-silica glasses, crystallization occurred with the addition of $30 \mathrm{w} / \mathrm{o}$ rare-earth oxide. Glasses containing the higher percentage of rare-earth oxide were very viscous and could not be poured easily at $1600^{\circ} \mathrm{C}$. 
These materials offer the advantage of having a very uniform dis tribution of the high-cross-section constituent in a solution and yet behaving as a solid at operating temperatures. The concentration of rare earth may be altered readily by dilution with the base glass. The control rod may be made entirely of a glassy material or can be a mixture of glass and some crystalline material, if such a system offers any additional advantages.

Boron carbide is a relatively inexpensive material that has found some application in control rods for thermal reactors. The fabrication of boron carbide into pellets or plates suitable for assembly into çontrol rods necessitates hot pressing, and this procedure is time-consuming and expensive. However, boron carbide has a high capture cross section for. thermal neutrons, and high densities are not necessary for most controlrod applications. Many control rods contain boron carbide grains compacted to densities of from 60 to $75 \%$ of theoretical $(1.50$ to $1.87 \mathrm{~g} / \mathrm{cc})$.

In some control-rod applications, the movement of the rod during normal reactor operations causes the boron carbide grains to fracture and settle in the tube. This leaves a void in one end of the control rod that may cause difficulty for the reactor operator. To alleviate this settling, a study was made of the development of an inexpensive method of fabricating boron carbide into shapes that would remain intact under mechanical shock.

Pellets of $\mathrm{B}_{4} \mathrm{C}-15 \mathrm{w} / \mathrm{o}$ glass could readily be formed by warmpressing in a steel mold at temperatures of 400 to $600^{\circ} \mathrm{C}$. These pellets had densities of 85 to $91 \%$ theoretical density $(2.13$ to $2.27 \mathrm{~g} / \mathrm{cc}$ ) of boron carbide and were very resistant to chipping by impact. This method could be used to produce shapes satisfactory for control-rod loadings.

A further development of the glass-bonded $B_{4} C$ control rod was the elimination of the pelletizing step. The density desired in the control rods is casily obtained by vibratory compaction of sized grains. A method was worked out whereby tubing would be filled to the desired density with a mixture of $\mathrm{B}_{4} \mathrm{C}$ and glass and bonded by heating the materials above the softening point of the glass.

A low-softening-point glass was made having a composition of $69.53 \mathrm{w} / \mathrm{oSiO}_{2}-19.84 \mathrm{w} / \mathrm{oK}_{2} \mathrm{O}-10.63 \mathrm{w} / \mathrm{oNa}_{2} \mathrm{O}$. After smelting, the glass was quenched and ground in alcohol to less than 150-micron size. Boron carbide of two sizes was used to provide a packing mixture. Boron carbide was blended in the ratio $70 \mathrm{w} / 0$ of $60-\mathrm{mesh}(250-$ micron) and $30 \mathrm{w} / \mathrm{o}$ of $325-$ mesh (44-micron) fractions.

A slurry was made of the glass by mixing with alcohol. The boron carbide mixture was added to the slurry in the proportions of $85 \mathrm{w} / \mathrm{o} \mathrm{B}_{4} \mathrm{C}$ to $15 \mathrm{w} / 0$ glass. The slurry was dried at $100^{\circ} \mathrm{C}$, and the dry glass-boron 
carbide mixture was vibrated, while warm, into stainless-steel tubes. Densities, as calculated from tube dimensions, ranged from 1.63 to $1.87 \mathrm{~g} / \mathrm{cc}$, or 65 to $75 \%$ of the theoretical density of boron carbide. No attempt was made to reach a higher packed density since these values were in the range desired for the application of the control rods.

The loaded tubes were lowered through an induction heating coil at a rate of $1.27 \mathrm{~cm} / \mathrm{min}$, and the stainless-steel tubing served as the susceptor for heating. The surface temperature of the rod was maintained near $900^{\circ} \mathrm{C}$ during the operation. The main problems encountered were oxidation and distortion of the metal tubes, and both were eliminated by passing the rod through a close-fitting, fused-quartz tube in an atmosphere of flowing argon. An assembly of 32 control rods was made in this manner for use in a critical-loading experiment.

\section{FABRICATION EXPERIMENTS}

Magnesia-glass mixtures were prepared by means of standard powder fabrication and sintering techniques to evaluate the usefulness of the glass as a sintering agent as well as a fuel carrier.

For this purpose, a glass was used containing $11 \mathrm{w} / \mathrm{oNa}_{2} \mathrm{O}-7.3 \mathrm{w} / \mathrm{oCaO}$ $33.2 \mathrm{w} / \mathrm{oUO}_{2}-48.5 \mathrm{w} / \mathrm{oSiO}_{2}$. The results of sintering various compositions are shown in Table V. Metallographic examination of the sintered samples showed the glassy phase to be well-dispersed throughout the MgO with partial solution of the $\mathrm{MgO}$ grains evident. Figure 7 is a polished section of a sample containing $10 \mathrm{w} / \mathrm{o}$ glass and sintered at $1650^{\circ} \mathrm{C}$.

TABLE V. Sintering Data for MgO-glass Mixtures

\begin{tabular}{|l|c|c|c|}
\hline \multirow{2}{*}{ Composition } & \multirow{2}{*}{$\begin{array}{c}\text { Sintering } \\
\text { Temperature, }{ }^{\circ} \mathrm{C}\end{array}$} & \% Theoretical (mixture) & \% Theoretical (MgO) \\
\cline { 3 - 4 } & 1500 & - & 60 \\
$\mathrm{MgO}$ & 1650 & - & 77 \\
$\mathrm{MgO}$ & 1725 & - & 77 \\
$\mathrm{MgO}$ & 1500 & 80 & 79 \\
$\mathrm{MgO}+5 \%$ Glass & 1650 & 90 & 89 \\
$\mathrm{MgO}+5 \%$ Glass & 1725 & 92 & 92. \\
$\mathrm{MgO}+5 \%$ Glass & 1500 & 91 & 90 \\
$\mathrm{MgO}+10 \%$ Glass & 1650 & 80 & 79 \\
$\mathrm{MgO}+10 \%$ Glass & 1725 & 93 & 92 \\
$\mathrm{MgO}+10 \%$ Giass & 1500 & 83 & 82 \\
$\mathrm{MgO}+15 \%$ Glass & 1650 & 92 & 91 \\
$\mathrm{MgO}+15 \%$ Glass & 1725 & 89 & 88 \\
$\mathrm{MgO}+15 \%$ Glass & & &. \\
\hline
\end{tabular}




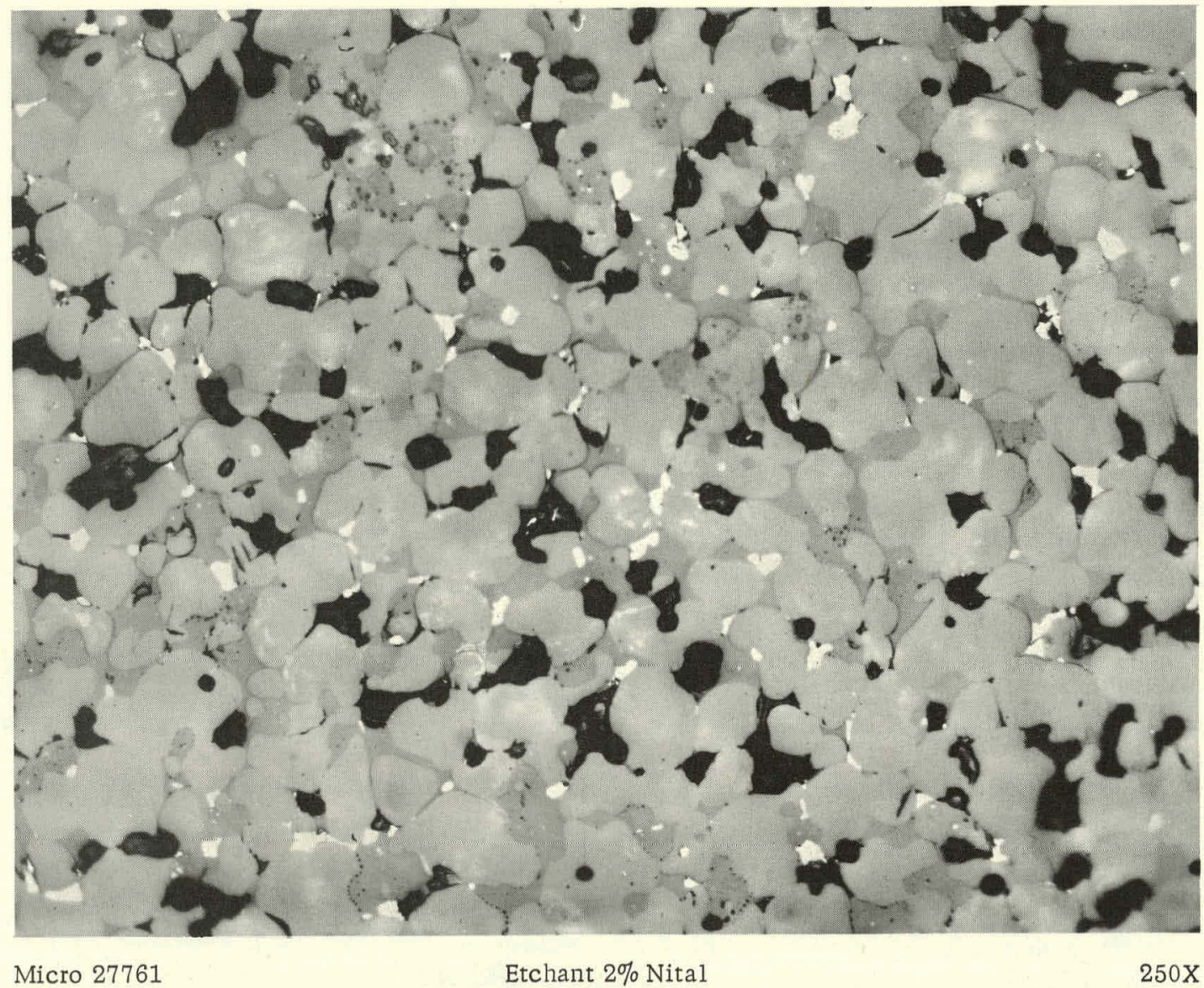

Fig. 7. $\mathrm{MgO}-10 \mathrm{w} / \mathrm{o}$ Glass Sintered at $1650^{\circ} \mathrm{C}$

Fabrication of several crystalline-glass mixtures was attempted by pressing and sintering at temperatures of $1000^{\circ} \mathrm{C}$ and lower. The crystalline materials used were $\mathrm{MgO}, \mathrm{SiC}$, fused $\mathrm{UO}_{2}$, spherical $\mathrm{UO}_{2}, \mathrm{UC}$, US, and ceramic-grade $\mathrm{UO}_{2}$. Glass contents in the range of 10 to $30 \mathrm{w} / \mathrm{o}$ were used.

Silicon carbide and $\mathrm{MgO}$ mixtures with glass were used to evaluate the temperature range and glass contents feasible for low-temperature sintering. Samples containing $30 \mathrm{w} / \mathrm{o}$ glass could be sintered at $700^{\circ} \mathrm{C}$ but slumped at higher temperatures. Samples containing $10 \mathrm{w} / \mathrm{o}$ glas s could be heated to $1000^{\circ} \mathrm{C}$ without deformation. Low-temperature sintering of these materials resulted in densities in the range of 80 to $90 \%$ of theoretical for the mixture.

Sound pellets were made by hydrogen sintering, at $600^{\circ} \mathrm{C}$, all mixtures containing 10 to $15 \mathrm{w} / 0$ glass, except compacts of UC and spherical $\mathrm{UO}_{2}$. $\Lambda$ compact of UC-glass was fabricated both in vacuum and in argon. 
Warm-pressing, at $600^{\circ} \mathrm{C}$, of glass mixtures containing SiC, fused $\mathrm{UO}_{2}$, spherical $\mathrm{UO}_{2}$, and $\mathrm{UC}$ resulted in compacts having approximately $90 \%$ of the theoretical density of the mixture.

Methods of fabricating fueled rods of $0.635-\mathrm{cm}$ diam $\times 8.89-\mathrm{cm}$ length were investigated. Direct casting of the molten glass into the metal jacket was unfeasible since a glass temperature of $1500^{\circ} \mathrm{C}$ was required for fluidity. Fragments of glass were compacted in a graphite die at $700^{\circ} \mathrm{C}$. It was possible to form rods approximately $3 \mathrm{~cm}$ long by this method.

The most successful method of forming long rods was extrusion. In this method, a cast slug of glass was inserted into a graphite die and heated to about $800^{\circ} \mathrm{C}$ to soften the glass. Approximately 0.35 metric ton $/ \mathrm{cm}^{2}$ was required to extrude the glass through a $0.635-\mathrm{cm}$ die. The mold design was such that the glass extruded through a $0.635-\mathrm{cm}$-diam x 5.08-cm-long opening to maintain shape while the glass cooled partially. An air blast was used for final cooling of the extrusion. Samples up to $12.7 \mathrm{~cm}$ long were extruded, and the size-limiting factor was the mold cavity for containing the glass slug.

Fabrication methods were not studied in detail; studies were only sufficient to demonstrate feasibility.

\section{GLASSY COATING MATERIALS}

Glassy materials have long been used as coatings for metals and other ceramics for the purpose of protection or to impart special properties.

The feasibility of'coating Zircaloy with a glass containing a highcross-section element was investigated. With use of a coating of this type it may be possible to introduce a burnable poison into the core of a thermal reactor. The coating could be applied to some structural element that is uniformly distributed throughout the core.

A commercial porcelain-enamel frit (Chicago Vitreous Corporation, No. 1485) developed for stainless steel was selected as suitable for trials. Zircaloy -2 was prepared by vapor-blasting, and the coating was applied by spraying a water suspension of the coating materials. Samples coated with a composition containing $5 \mathrm{w} / 0 \mathrm{Gd}_{2} \mathrm{O}_{3}$ required heating at $880^{\circ} \mathrm{C}$ for 3 min to mature the coating and develop adherence. An excellent-appearing coating of 1 -mil thickness was produced on 25-mil Zircaloy-2.

The use of a glass-coated ceramic was proposed for the solution of a problem for the Biology Division of ANL. It was desired to construct an irradiation capsule for small animals in which $\mathrm{Sr}^{90}$ would be used as the source of beta emission. The two main requirements to be met were that 
the radioactivity level be uniform throughout the capsule and that the $\mathrm{Sr}^{90}$ be contained so that there was negligible loss due to corrosive attack by acids, bases, organic solvents, and mechanical abrasion. It was proposed to use a porcelain tube for the capsule and to incorporate the $\mathrm{Sr}^{90}$ in a glass coating (glaze) to be applied to the interior surface of the tubing.

Glaze compositions were not studied in detail since commercial materials were available. Acid-solubility tests were used to select the most promising materials for use as the glaze. The major problems were associated with the handling of $\mathrm{Sr}^{90}$ and the application of the glaze to insure uniform distribution of the $\mathrm{Sr}^{90}$.

The $\mathrm{Sr}^{90}$ was supplied as a solution in $1 \mathrm{~N} \mathrm{HCl}$ and had an activity level of $37.8 \mu \mathrm{Ci} / \mathrm{cc}$. The low concentration necessitated the addition of a relatively large volume of $\mathrm{HCl}$ to the glaze. Because of the large acid addition, it was necessary to work with glazes that were composed essentially of fritted material to prevent reactions with the acid. Due to hazards involved in handling $\mathrm{Sr}^{90}$, all work was carried out in enclosed hoods and glazing firing was done in a sealed furnace chamber.

Safety precautions prevented the use of the usual spraying or dipping techniques for glaze application. A uniform glaze deposit was achieved

TABLE II. Cumulative Weight Loss (in grams) for Glazed Porcelain Tubing* Subjected to Chemical Attack

\begin{tabular}{|c|c|c|c|c|c|c|}
\hline \multirow{2}{*}{\multicolumn{2}{|c|}{ Glaze Sample }} & \multicolumn{5}{|c|}{ Time, $\mathrm{hr}$} \\
\hline & & 1 & 2 & 3 & 8 & 12 \\
\hline I. & $6 \mathrm{~N} \mathrm{HCl}$ at Room Temperature & & & & & \\
\hline & $\begin{array}{l}\text { Standard tube } \\
f-1 \\
F-2\end{array}$ & $\begin{array}{l}0.002 \\
0.007 \\
0.000\end{array}$ & $\begin{array}{l}0.002 \\
0.009 \\
0.000\end{array}$ & $\begin{array}{l}0.002 \\
0.013 \\
0.000\end{array}$ & $\begin{array}{l}0.002 \\
0.021 \\
0.000\end{array}$ & $\begin{array}{l}0.002 \\
0.023 \\
0.000\end{array}$ \\
\hline II. & Boiling $6 \mathrm{~N} \mathrm{HCl}\left(104^{\circ} \mathrm{C}\right)$ & & & & & \\
\hline & $\begin{array}{l}\text { Standard Tube } \\
F-1 \\
F-2\end{array}$ & $\begin{array}{l}0.000 \\
0.008 \\
0.006\end{array}$ & $\begin{array}{l}0.000 \\
0.009 \\
0.007\end{array}$ & $\begin{array}{l}0.000 \\
0.012 \\
0.009\end{array}$ & $\begin{array}{l}0.000 \\
0.015 \\
0.012\end{array}$ & $\begin{array}{l}0.000 \\
0.018 \\
0.013\end{array}$ \\
\hline III. & $6 \mathrm{~N} \mathrm{HNO}_{3}$ at Room Temperature & & & - & & \\
\hline & $\begin{array}{l}\text { Standard tube } \\
\text { F-1 } \\
F-2\end{array}$ & $\begin{array}{l}0.001 \\
0.002 \\
0.002\end{array}$ & $\begin{array}{l}0.001 \\
0.002 \\
0.002\end{array}$ & $\begin{array}{l}0.001 \\
0.004 \\
0.002\end{array}$ & $\begin{array}{l}0.001 \\
0.004 \\
0.002\end{array}$ & $\begin{array}{l}0.001 \\
0.005 \\
0.004\end{array}$ \\
\hline IV. & Boiling $6 \mathrm{~N} \mathrm{HNO}_{3}\left(107^{\circ} \mathrm{C}\right)$ & & & & & \\
\hline & $\begin{array}{l}\text { Standard tube } \\
\text { F-1 } \\
F-2\end{array}$ & $\begin{array}{l}0.001 \\
0.000 \\
0.000\end{array}$ & $\begin{array}{l}0.001 \\
0.002 \\
0.001\end{array}$ & $\begin{array}{l}0.001 \\
0.002 \\
0.002\end{array}$ & $\begin{array}{l}0.001 \\
0.002 \\
0.002\end{array}$ & $\begin{array}{l}0.001 \\
0.002 \\
0.003\end{array}$ \\
\hline
\end{tabular}

-Exposed surface area $=21.74 \mathrm{~cm}^{2}$.

\section{Glaze Compositions}

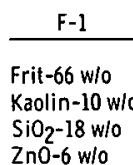

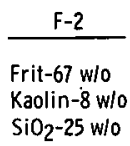

\begin{tabular}{ll}
\multicolumn{2}{c}{ Empirical Formula of Frit } \\
\hline $0.025 \mathrm{Na}_{2} \mathrm{O}$ & $0.267 \mathrm{ZnO}$ \\
$0.071 \mathrm{~K}_{2} \mathrm{O}$ & $0.206 \mathrm{PbO}^{2}$ \\
$0.320 \mathrm{CaO}$ & $0.187 \mathrm{Al}_{2} \mathrm{O}_{3}$ \\
$0.083 \mathrm{BaO}$ & $1.34 \mathrm{SiO}_{2}$ \\
$0.022 \mathrm{MgO}$ &
\end{tabular}
by simultaneously rotating the porcelain tube and adding the glaze through a pipette. After the tube was rotated for a predetermined time, the excess glaze was drained out and the $\mathrm{Sr}^{90}$ solution was introduced through a calibrated pipette. After the $\mathrm{Sr}^{90}$ solution was added, a blast of hot air was directed against the outside of the tube, while rotating, to speed drying and to reduce exposure time. The glaze was fired in a sealed furnace chamber. As a final protective step, a thin film of palladium was applied to the finished glaze surface and heated to $680^{\circ} \mathrm{C}$ to form a bond. Finished tubes were checked for surface contamination prior to use. Glaze compositions and stability to corrosion are listed in Tables VI and VII. 
TABLE VII. Solubility of $\mathrm{Sr}^{90}$ for Glazes Subjected to Chemical Attack at Room Temperature

\begin{tabular}{|c|l|c|c|}
\hline Glaze & Solution & Time, hr & Loss, $\mu \mathrm{Ci}$ \\
\hline F-I & $\mathrm{H}_{2} \mathrm{O}$ & 24 & 0.0033 \\
& $1 \mathrm{~N} \mathrm{HCl}$ & 2 & 0.0085 \\
& $6 \mathrm{~N} \mathrm{HCl}$ & 2 & 0.0023 \\
$\mathrm{~F}-2$ & 6 & 24 & 0.0039 \\
& $\mathrm{H}_{2} \mathrm{O}$ & 2 & 0.0050 \\
& $1 \mathrm{~N} \mathrm{HCl}$ & 2 & 0.0023 \\
\hline
\end{tabular}

\section{PRODUCTION OF DOPPLER-COEFFICIENT SAMPLES}

For measurements of Doppler coefficient, a fuel was desired that had a relatively low density ( $70 \%$ of theoretical) and essentially zero expansion up to $1000^{\circ} \mathrm{C}$. These general specifications precluded the use of normally sintered oxide; however, it was found feasible to form the lowdensity specimens by bonding $\mathrm{UO}_{2}$ grains with a glass phase. During heating, the change in viscosity of the glass allowed for grain-shifting and absorbed the expansion of the grains, with the result that there was essentially no change in the size of the specimen when heated to $1000^{\circ} \mathrm{C}$.

The urania specimens of normal enrichment were produced by applying a fluidized-bed technique to spherical particles prepared by the Chemical Engineering Division. The material, as produced; was 70 to $80 \%$ of theoretical density and was sintered in vacuum at $1750^{\circ} \mathrm{C}$ to increase the particle density to $95 \%$ of theoretical. The spheres were mixed with $1 \mathrm{w} / 0$ sodium metasilicate and fabricated to shape by pressing. The specimens were then heated in hydrogen at $1200^{\circ} \mathrm{C}$ to form the glassy bond.

Urania specimens of $97 \%$ enrichment.were also produced. The granular material used for these specimens was prepared by isostatic compaction of the fine powder, followed by crushing and screening to separate grains in the $250-$ to $150-$ micron size range. These particles were then sintered, in vacuum, at $1750^{\circ} \mathrm{C}$ for densification to approximately $95 \%$ of theoretical density. Glass bonding was accomplished as described previously.

Doppler-coefficient samples were also prepared from plutonium oxide and mixed plutonium-uranium oxides. The fabrication techniques were essentially the same as those described for $\mathrm{UO}_{2}$, except that sintering steps were carried out in helium. 
The details of the manufacture of the urania and the plutoniabearing Doppler coefficient samples are the subjects of other reports* of the Laboratory.!

\section{GLASS-BONDED IRRADIATION SAMPLES}

Assistance was given to the Engineering Irradiation group in the fabrication of glass-bonded boron carbide samples for irradiation studies.

Three types of glasses were chosen for the initial work in order to provide a spread of softening temperatures between 400 and $600^{\circ} \mathrm{C}$. The compositions of these glasses are shown in Table VIII.

TAB LE-VIII. Compositions of Glasses Used in Irradiation Samples

\begin{tabular}{|c|c|c|}
\hline Lead Glass & Soda-Potash Glass & Soda-Lime Glass \\
\hline $63.3 \mathrm{w} / \mathrm{o} \mathrm{PbO}$ & $9.3 \mathrm{w} / 0 \mathrm{Na}_{2} \mathrm{O}$ & $15.8 \mathrm{w} / \mathrm{o} \mathrm{Na}_{2} \mathrm{O}$ \\
\hline $8.7 \mathrm{w} / \mathrm{o} \mathrm{Na}_{2} \mathrm{O}$ & $19.3 \mathrm{w} / \mathrm{o} \mathrm{K} \mathrm{K}_{2} \mathrm{O}$ & $10.2 \mathrm{w} / \mathrm{o} \mathrm{CaO}$ \\
\hline $2.0 \mathrm{w} / \mathrm{o} \mathrm{Al}_{2} \mathrm{O}_{3}$ & $2.0 \mathrm{w} / \mathrm{o} \mathrm{Al}_{2} \mathrm{O}_{3}$ & $2.0 \mathrm{w} / \mathrm{o} \mathrm{Al}_{2} \mathrm{O}_{3}$ \\
\hline $26.0 \mathrm{w} / \mathrm{o} \mathrm{SiO}_{2}$ & $69.4 \mathrm{w} / 0 \mathrm{SiO}_{2}$ & $72.0 \mathrm{w} / \mathrm{o} \mathrm{SiO}_{2}$ \\
\hline Density $4.68 \mathrm{~g} / \mathrm{cc}$ & $2.42 \mathrm{~g} / \mathrm{co}$ & $2.54 \mathrm{~g} / \mathrm{cc}$ \\
\hline
\end{tabular}

Glass compositions were melted at $1400^{\circ} \mathrm{C}$, water-quenched, and crushed to less than 100-mesh sieve size. Previous tests had shown that a satisfactory density could be obtained by vibratory compaction of a mixture of $70 \mathrm{w} / \mathrm{o}$ of $65-$ mesh $\mathrm{B}_{4} \mathrm{C}$ particles and $30 \mathrm{w} / \mathrm{o}$ of $325-\mathrm{mesh}_{4} \mathrm{C}$ particles. Boron carbide, in this ratio, was blended with the desired amount of glass in a cone blender for $30 \mathrm{~min}$. Following this initial mixing, the particles. were blended with alcohol, to a thin-paste consistency, and dried before compaction. Blending the mixed materials with alcohol resulted in a coating of glass on the $\mathrm{B}_{4} \mathrm{C}$ particles.

*aJ. E. Ayer, A. G. Hins, D. E. White, D. C. Carpenter, and C. F. Konicek, The Manufacture of Glass-bonded Fuels for Doppler Coefficient Measurement, ANL-6995 (March 196.5).

bD. E. White and J. H. Handwerk, The Fabrication of Glass-bonded Uranium Dioxide Elements for Doppler Coefficient Measurements, ANL-7069 (to be iseued). 
Sample tubes were filled with the mixture, which was then vibrationally compacted to approximately $70 \%$ of theor'etical density of the $\mathrm{B}_{4} \mathrm{C}$. The final step in the preparation of samples consisted of bonding the particles by heating above the softening temperature of the glass. The bonding was accomplished by lowering the filled tube, at a controlled rate, through a resistance furnace. The furnace temperature and rate of lowering were varied to suit the particular blend and type of glass. In general; a temperature of $550^{\circ} \mathrm{C}$ and a rate of lowering of $2.54 \mathrm{~cm} / \mathrm{min}$ were satisfactory for most compositions.

Satisfactory samples were prepared of mixtures containing from 15 to $90 \mathrm{w} / \circ \mathrm{B}_{4} \mathrm{C}$. The lead-bearing glass was found to be unsatisfactory due to the reduction of the glass by the $\mathrm{B}_{4} \mathrm{C}$ to yield metallic-lead particles.

\section{SUMMARY}

A preliminary study was made of the effects of urania additions on some properties of selected glasses in the systems $\mathrm{PbO}-\mathrm{Na}_{2} \mathrm{O}-\mathrm{SiO}_{2}$; $\mathrm{Na}_{2} \mathrm{O}-\mathrm{CaO}-\mathrm{SiO}_{2}, \mathrm{Na}_{2} \mathrm{O}-\mathrm{SiO}_{2}$, and $\mathrm{Na}_{2} \mathrm{O}-\mathrm{K}_{2} \mathrm{O}-\mathrm{SiO}_{2}$. Properties of interest were those that might determine their usefulness as.a reactor fuel, namely, devitrification resistance, urania solubility, and density.

The addition of urania to $\mathrm{PbO}-\mathrm{Na}_{2} \mathrm{O}-\mathrm{SiO}_{2}$ glass decreased the devitrification resistance of the base glass. The original glass was resistant to devitrification, but the addition of as little as $9 \mathrm{w} / 0 \mathrm{UO}_{2}$ caused crystallization to occur in a short time.

A single-phase glass was produced containing up to $60 \mathrm{w} / \mathrm{O} \mathrm{UO}_{2}$ by the addition of urania to a $\mathrm{Na}_{2} \mathrm{O}-\mathrm{CaO}-\mathrm{SiO}_{2}$ glass. Glasses containing up to approximately $40 \mathrm{w} / \mathrm{O} \mathrm{UO}_{2}$ were resistant to devitrification below $700^{\circ} \mathrm{C}$.

Urania-bearing glasses based on the composition $\mathrm{Na}_{2} \mathrm{Si}_{2} \mathrm{O}_{5}$ were found to be resistant to devitrification when held at temperatures above or below the range of $600-800^{\circ} \mathrm{C}$.

The most promising glasses were based on compositions in the system $\mathrm{Na}_{2} \mathrm{O}-\mathrm{K}_{2} \mathrm{O}-\mathrm{SiO}_{2}$. Compositions containing equivalent to about $60 \mathrm{w} / 0 \mathrm{UO}_{2}$ were melted to single-phase glasses at $1500^{\circ} \mathrm{C}$. Glasses containing up to $30 \mathrm{w} / \mathrm{o} \mathrm{UO}_{2}$ were extremely resistant to devitrification. Several compositions within this maximum range were maintained for 14 days in a gradient of $300-950^{\circ} \mathrm{C}$ without crystalline development, and one sample containing approximately $20 \mathrm{w} / \mathrm{O} \mathrm{UO}_{2}$ has been held in the same temperature gradient for 100 days without devitrification. 
Rare-earth glasses were prepared that would dissolve $30 \mathrm{w} / \mathrm{o}$ of $\mathrm{Gd}_{2} \mathrm{O}_{3}, \mathrm{Dy}_{2} \mathrm{O}_{3}, \mathrm{Gd}_{2} \mathrm{O}_{3}-\mathrm{Sm}_{2} \mathrm{O}_{3}$, and $\mathrm{Eu}_{2} \mathrm{O}_{3}$ when melted at $1500^{\circ} \mathrm{C}$. Glasses. containing up to $15 \mathrm{w} / 0$ oxide additions were resistant to devitrification when reheated in a temperature grädient.

Glassy materials were found to be useful for bonding $\mathrm{B}_{4} \mathrm{C}$ grains for control-rod use. Vibratory compacted mixtures of $\mathrm{B}_{4} \mathrm{C}$-glass were fused together by lowering through an induction coil. The control rods produced were resistant to segregation of the $B_{4} C$ due to vibration in use.

Various fabrication methods were used to examine the feasibility of fabricating crystalline-glass mixtures. Mixtures were fabricated by dry-pressing and sintering and by warm-pressing in steel dies at $600^{\circ} \mathrm{C}$. Long rods $(5.08 \mathrm{~cm}$ ) of material were fabricated by extrusion through graphite dies at $800^{\circ} \mathrm{C}$. 


\section{APPENDIX}

\section{Construction of Gradient Furnace}

A special feature of the gradient furnace built for these studies was that the glass under test could be observed from the top of the furnace along the entire sample length. The furnace was designed in this manner to enable observation of the sample, either with the naked eye or with a microscope, without disturbing the position of the sample during the test.

The tube used for the furnace was a recrystallized-alumina sheath $2.54 \mathrm{~cm}$ ID and $45.72 \mathrm{~cm}$ long. A slit $0.635 \mathrm{~cm}$ wide and $17.78 \mathrm{~cm}$ long was cut in the central portion of the tube. On the two edges thus created, grooves were cut in at predetermined spacings, so that they had a comb-like appearance. The spacings used were such that the first $2.54 \mathrm{~cm}$ had 12 grooves, the second 10 , the third eight, the fourth six, the fifth four, and the sixth two.

Platinum-10\% rhodium wire was considered a convenient heating element, and 24-gauge wiṛe was suitable for this furnace. Power control was by means of a Variac on the 110-volt, 60-cycle, single-phase circuit. The wire was wound around the tube and reversed around the grooves on either side of the slit. Thus, the wire was held in position and at proper spacing, with no wire crossing over the slit, that was to be used for viewing the sample. Alumina cement was applied over the windings to fix them in position and prevent contact with other insulating materials used.

The casing for the furnace was a Transite box (15.24 x $15.24 \mathrm{x}$ $60.96 \mathrm{~cm}$ ), and the top plate of the casing was fixed by screws so that it could be easily removed for assembly of the furnace. Insulation brick was used adjacent to the box, and bubble alumina casting mix between the tube and the insulation brick. (The bricks were cut so as to form a chamber of $5.08 \times 5.08 \times 45.72 \mathrm{~cm}$ in which the alumina tube was placed.) A slit of $0.635 \times 20.32 \mathrm{~cm}$ was made through the layers of insulation and in the top plate. A quartz window was fixed about $1.27 \mathrm{~cm}$ above the slit on the tube, and a Vycor window was mounted flush with the top of the Transite plate. This design permitted visibility of the sample, at the same time minimized heat losses. In this apparatus, the reflecting microscope was to be used for observation; hence, the insulation was limited to keep the distance between the sample and the top of the furnace less than $10.16 \mathrm{~cm}$, for focus ing the microscope.

The electrical leads were connected from the top of the furnace. A. Variac with a constant-voltage transformer was used on 110-V, 60-cycle, single-phase. This system was preferred because it assured a constant gradient and allowed the furnace to stabilize, and the strain on the heating element would be much less than on an on-off system. 
Temperature was measured with a $\mathrm{Pt}-\mathrm{Pt}-10 \mathrm{Rh}$ thermocouple. A $45.72-\mathrm{cm}$ thermocouple was held in a single-piece, twin-bore, ceramic insulator. The thermocouple was connected to a potentiometer capable of measuring to $0.005 \mathrm{mV}$. The thermocouple could thus be moved to various positions in the furnace (along the sample), and the exact desired position could be viewed and measured from the top.

The sample holders were 0.635-cm-wide, $17.78-\mathrm{cm}-1$ long, and $0.635-\mathrm{cm}$-high platinum boats fabricated from thin sheets. The boat was placed on an insulating brick platform $(1.27 \mathrm{~cm} \times 20.32 \mathrm{~cm}$ long $\times 0.635 \mathrm{~cm}$ thick), that could easily be pushed into and pulled out of the furnace. This not only provided a surface for the boats to rest on, but also made sure that no glass fell on the tube.

A permanent calibration of the furnace was not attempted because the location of the boat at exactly the same position in various tests would not be possible. A gradient of about $600^{\circ} \mathrm{C}$ in $15.24-\mathrm{cm}$ length was established, and the shift of the boat by even $0.25 \mathrm{~cm}$ would result in a difference of $10^{\circ} \mathrm{C}$. Temperatures were measured along the side of the boat, starting from the hot end, at sufficient intervals to yield the desired data pattern. 


\section{ACKNOW LEDGMENT}

The author wishes to acknowledge Messrs. J. H. Handwerk and D. R. Lankard for their efforts on several phases of this work. Special acknowledgment is made to V. K. Moorthy who made the initial studies while participating as a Resident Research Associate at Argonne. 